\title{
Problemy spawalnicze przy modernizacji starych mostów kolejowych
}

\author{
Welding issues in retrofitting of old railway bridges
}

\section{Streszczenie}

Niepełne, a nieraz zróżnicowane przedstawianie wymagań normowych oraz ich mnogość jest w ostatnim okresie przyczyną różnej interpretacji tych samych zagadnień konstrukcyjnych. Podobny przypadek dotyczący połączeń spawanych podczas modernizacji dwóch mostów kolejowych przedstawiono w referacie.

Słowa kluczowe: mosty stalowe, stal zlewna, spawalność stali

\begin{abstract}
Long lifespan of railway bridges causes technical and functional ageing of the structuresas well as the material degradation. Serviceability parameters of such structures are worsened and the structural steels are aging structurally. The problem is presented by results of research work on structural steels in two railway truss bridges.

Many different code requirements and their complexity may cause different interpretations of the same structural issue. The similar case had happened for welded connections in retrofitting of the two railway bridges which are presented in the paper.
\end{abstract}

Keywords: steel bridges, cast steel, weldability

\section{Wstęp}

Każda konstrukcja eksploatowana przez czas dłuższy podlega degradacji techniczno-funkcjonalnej oraz materiałowej. Następuje pogorszenie walorów użytkowych konstrukcji oraz starzenie strukturalne stali. Problem ten dotyczy w szczególności starych obiektów mostowych, które zaliczamy do najdłużej użytkowanych naziemnych budowli inżynierskich $[1 \div 4]$. W mostach tych, poza standardowymi problemami utrzymaniowymi, występują również zagadnienia materiałowe, które trzeba rozpoznać w celu określenia wytrzymałości obliczeniowej oraz spawalności przy wzmacnianiu lub przebudowie z wykorzystaniem spawania. Stosowanie metod napraw i wzmacniania za pomocą dospawania elementów prowadzi do wymiernych oszczędności ekonomicznych i ułatwień w utrzymaniu ciągłości ruchu komuni-

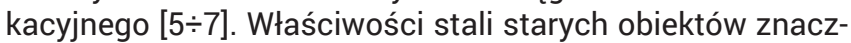
nie różnią się od właściwości stali wytwarzanych obecnie, dlatego też w przypadku każdej przebudowywanej konstrukcji występuje problem możliwości spawania jej materiału i bezpiecznej pracy połączeń spawanych. Zagadnienie spawalności stali niskowęglowych sprowadza się do pęknięć

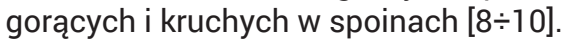

Żadna dawna stalowa konstrukcja mostowa nie powinna być zakwalifikowana do przebudowy lub wzmocnienia za pomocą spawania jeśli nie zostaną przeprowadzone badania spawalności stali, z której konstrukcja ta została wy-

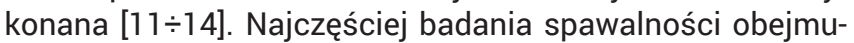

ją: analizę składu chemicznego stali elementów nośnych, określenie właściwości mechanicznych $\left(R_{m}, R_{e}\right.$ i $A$ \%) i badania udarnościowe na próbkach Charpy'ego (KCV).

Niekiedy uzyskane wyniki są zróżnicowane dla poszczególnych przęseł badanego mostu [3,6,10,15,16], a niekiedy wyniki badań są odmiennie interpretowane. Taki przypadek, różnej oceny spawalności stali dwóch mostów kolejowych wybudowanych w roku 1875, przedstawiono w niniejszym referacie. Zagadnienia modernizacyjno-badawcze tych mostów są tematem referatu [17], który został zgłoszony na tegoroczną XXVII Konferencję "Awarie Budowlane".

\section{Konstrukcja i historia mostów}

Dwa przedmiotowe mosty kolejowe usytuowane są na dwutorowej zelektryfikowanej linii kolejowej nr 273 Wrocław-Szczecin, na szlaku Chyrzyno-Kostrzyn nad polderem i rzeką Wartą (rys. 1). Są to wieloprzęsłowe konstrukcje kratownicowe górą otwarte z jezdnią dołem. Obiekt A jest konstrukcją pięcioprzęsłową o rozpiętościach: 39,65; 30,00; $39,65+40,40+39,65 \mathrm{~m}$, a obiekt B konstrukcją ciągłą trzyprzęsłową o jednakowych rozpiętościach 30,12 m. Całkowite długości tych mostów, mierzone po osi obiektu, wynoszą: 192,76 i 91,45 m. Dźwigary kratowe o pasach równoległych mają wysokość $4,20 \mathrm{~m}$, a ich rozstaw poprzeczny wynosi 4,90 i 5,00 m. Nawierzchnia kolejowa wykonstruowana była z szyn UIC60/S60 na mostownicach drewnianych,

Dr inż. Janusz Hołowaty, dr hab. inż. Bernard Wichtowski, prof. ZUT - Zachodniopomorski Uniwersytet Technologiczny w Szczecinie

Autor korespondencyjny/Corresponding author. jah@wp.pl 
o przekroju poprzecznym 0,22×0,24 m, opartych bezpośrednio na stopkach górnych dwuteowych podłużnic (rys. 2a i3a). Rozstaw osi torów wynosi 6,20 m.

Szlak kolejowy Chyrzyno-Kostrzyn został oddany do eksploatacji w 1875 roku. W latach 1970 i 1983 mosty zostały poddane modernizacji. W ich wyniku wybudowano nowe konstrukcje dwóch przęseł mostu A, w torze nr 1 od strony Wrocławia oraz wszystkie przęsła obu mostów w torze nr 2 (1983 r.). Nowe konstrukcje wykonano ze stali St3M. Obecnie z roku 1875 pozostały jedynie kratownicowe ciągłe konstrukcje trójprzęsłowe w torze nr 1 obu mostów, wykonane ze stali zlewnej o podwyższonej wytrzymałości.

Obecna modernizacja, przeprowadzona w roku 2014, miała na celu doprowadzenie konstrukcji mostów do wymogów instrukcji Id-2 (D-2) „Warunki techniczne dla kolejowych obiektów inżynieryjnych" oraz Id-1 (D-1) „Warunki techniczne utrzymania nawierzchni na liniach kolejowych". Projekt techniczny remontu opracował jeden $z$ autorów niniejszego referatu. Przewidywał on prace spawalnicze w ograniczonym zakresie. Ograniczały się one do przyspawania podkładek centrujących do pasów górnych podłużnic pod oparcia mostownic. Obecnie mostownice muszą być oparte na specjalnych podkładkach i siodełkach zgodnie z rysunkami $2 \mathrm{~b}$ i 3b. Podkładki centrujące o szerokości $40 \mathrm{~mm}$ i minimalnej wysokości $50 \mathrm{~mm}$ oraz długości $220 \mathrm{~mm}$ mają zmienną wysokość po długości przęsła w zależności od strzałki jego ugięcia [18]. Podkładki te z podłużnicami tradycyjnie łączone są obwodową spoiną pachwinową. Projekt przewidywał ich wykonanie, po rozpoznaniu parametrów stali i doborze odpowiedniej technologii spawania, zwłaszcza dla przęseł wykonanych ze stali zlewnej (1875 r.), które odbudowane zostały po zniszczeniach wojennych i ciągle znajdują się w eksploatacji.

\section{a)}
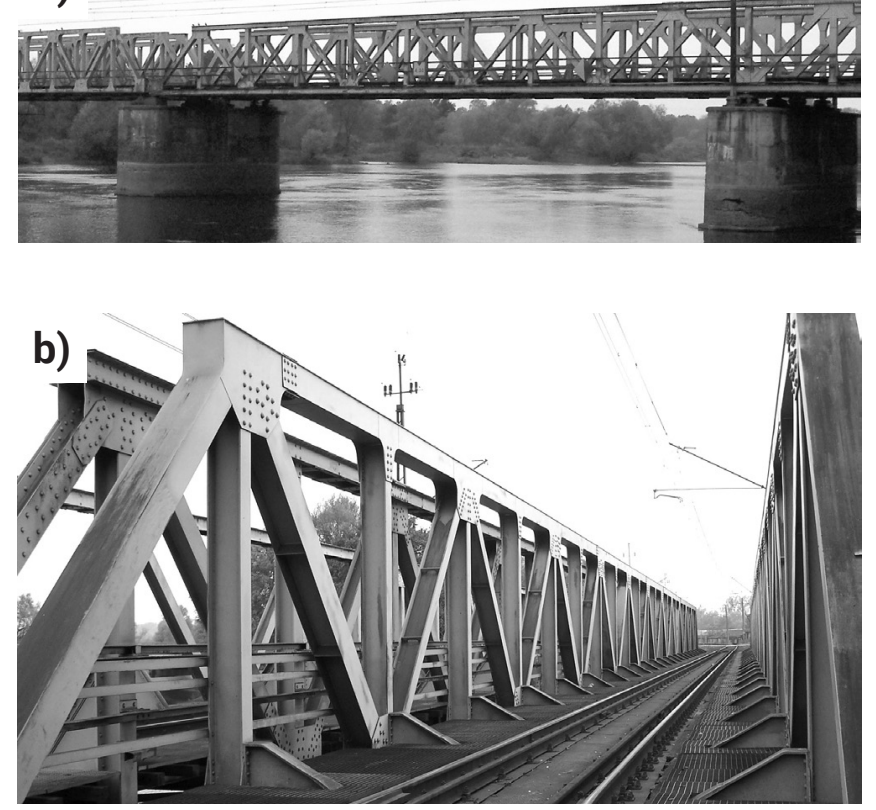

Rys. 1. Widok mostów A i B usytuowanych w odległości $284 \mathrm{~m}$ Fig. 1. View of bridges $A$ and $B$ located at a distance of $284 \mathrm{~m}$

a)

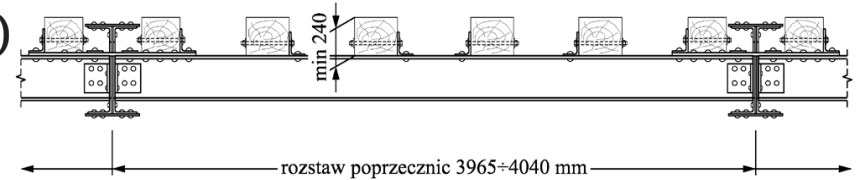

\section{Badania materiałowe i spawalnicze stali mostów}

Podczas wykonywania prac remontowych przedmiotowych mostów inspektor nadzoru wymagał sprawdzenia gatunku stali i jej spawalności. Dlatego też Wykonawca remontu zwrócił się o opinię dotyczącą możliwości wykonania spawania do Instytutu Spawalnictwa (IS) w Gliwicach. Ocenę spawalności stali mostów określoną na podstawie badań próbek materiałowych IS przedstawił w orzeczeniu [20]. Omówiono tam:

- analizę chemiczną badanych stali,

- wyniki próby statycznego rozciągania,

- badania udarnościowe,

- analizę spawalności.
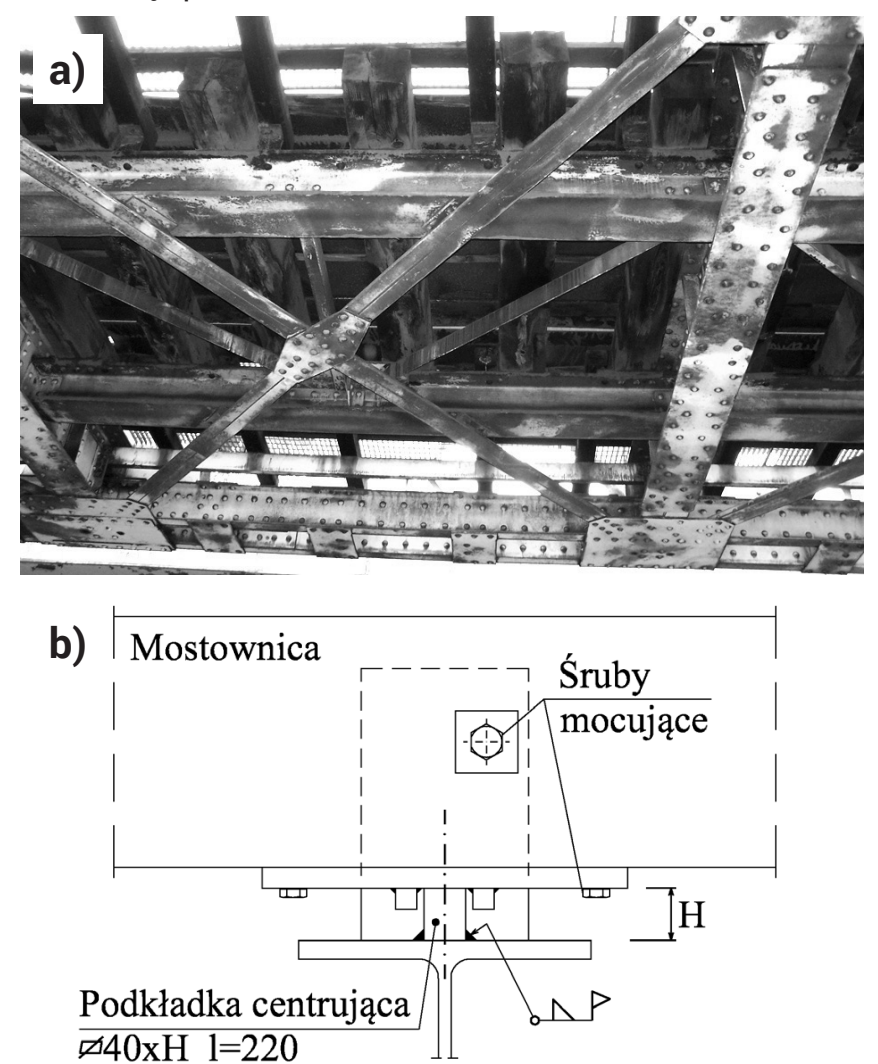

Rys. 3. Oparcie mostownic: a) bezpośrednio na pasach górnych podłużnic, b) na podkładkach centrujących

Fig. 3. Support of bridge sleepers: a) directly on the upper flanges of the stringers, b) on centring devices

Możliwość spawania uwzględnioną w projekcie modernizacyjnym mostów przyjęto również według wyników powyższych badań i dlatego w referacie dokonano ich porównania. W analizie uwzględniono jedynie badania porównywalne, bazując na wartościach średnich. Nie uwzględniono wyników z badań próbek pobranych w poprzek kierunku walcowania oraz próbek normalizowanych $[17,20]$.

Skład chemiczny stali dźwigarów mostowych określono za pomocą spektrometrów emisyjnych iskrowych firmy HORIBA JOBIN VON oraz BRUKER. W badaniach własnych

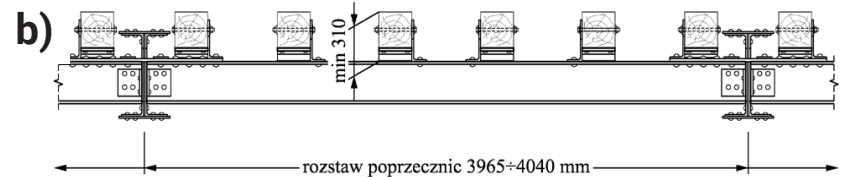

Rys. 2. Przęsło podłużnicy z oparciem mostownic: a) bezpośrednio na pasach górnych podłużnic (przed modernizacją), b) na podkładkach centrujących (po modernizacji)

Fig. 2. Stringer span with bridge sleepers supported: a) directly on the top flanges of the stringers (before refurbishment), b) on centring devices (after refurbishment) 
(BW) autorzy referatu analizie poddali 16 próbek wyciętych z rejonów podporowych pasów dolnych poszczególnych kratownic nośnych, a w badaniach IS trzy próbki wycięte z prętów wykratowania dźwigarów przęsła 1 i 2 (Stal St3M) oraz przęsła 4, tj. środkowego trójprzęsłowej konstrukcji od strony Szczecina (stal zlewna), w torze nr 1 mostu A. Określony skład chemiczny stali próbek wyciętych z powyższych elementów kratownic zamieszczono $w$ tablicy I. Jednocześnie w celach porównawczych podano tam skład chemiczny stali:

a) zlewnej, która była stosowana w okresie budowy mostu,

b) St3M i 18G2A stosowanej $w$ mostownictwie w okresie przebudowy omawianych przęseł, według $\mathrm{PN}-\mathrm{H}-$ 84023/04:1980 i PN-H-84018:1986.

Z porównania składu chemicznego poszczególnych gatunków stali (por. tabl. I) wynika, że analizowane przęsła mostu A zostały wykonane ze stali St3M oraz stali zlewnej gatunku St48 lub StSi o $R_{m, \text { min }}=520 \mathrm{MPa}$ i $R_{e, \text { min }}=360 \mathrm{MPa}$ [21]. Są to stale o właściwościach późniejszej stopowej stali zlewnej oznaczonej symbolem St52 (hochwertiger Baustahl), o właściwościach polskiej stali 18G2A [17].

Zaskakującym jest stwierdzenie zawartości węgla o wartości 0,201\% w badaniach jednej próbki ze stali St3M wyciętej z przęsła skrajnego mostu A od strony Wrocławia. Jest to wartość maksymalna określana przez PN-89/H-84023/04 dla tego gatunku stali. W dwóch pozostałych próbkach wyciętych z tego przęsła zawartość $C$ wynosiła jedynie: 0,104 i $0,124 \%$. Wzrost zawartości C w stali pogarsza jej spawalność. Oprócz węgla również inne pierwiastki zawarte w stali pogarszają jej spawalność. W celu uwzględnienia wpływu tych pierwiastków na spawalność stali mostowej obliczono wartość równoważnika węgla z poniższej zależności wg PNEN 1025-1: 2007P

$$
\mathrm{C}_{\mathrm{e}}=\mathrm{C}+\frac{\mathrm{Mn}}{6}+\frac{\mathrm{Cr}+\mathrm{Mo}+\mathrm{V}}{5}+\frac{\mathrm{Ni}+\mathrm{Cu}}{15}
$$

Określone w tablicy I wartości równoważnika węgla wynoszą od 0,25 do $0,43 \%$. Ze zmniejszaniem się równoważnika węgla skłonność stali do pękania maleje. Praktycznie ustalono, że jeżeli Ce $<0,45 \%$ i twardość w SWC nie przekracza $350 \mathrm{HV}$, to stal jest dobrze spawalna i prawdopodobieństwo powstania pęknięć jest znikome. Dla analizowanej stali utwardzenie w strefie wpływu ciepła ma wartości [18]:

$$
\mathrm{C}_{\mathrm{e}}=1200 \mathrm{C}_{\mathrm{e}}-260=40 \mathrm{HV} \text {, }
$$

$$
\mathrm{HV}_{\max }=1200 \mathrm{C}_{\mathrm{e}}-200=316<350 \mathrm{HV}
$$

Statyczną próbę rozciągania stali z pasa dolnego dźwigarów kratownicowych w torze $\mathrm{nr} 1$ mostu $A$, podczas badań własnych (BW), przeprowadzono na 21 próbkach okrągłych o średnicy bazowej $6 \mathrm{~mm}(2 \times 3=6$ sztuk $)$ i $8 \mathrm{~mm}(5 \times 3=15$ sztuk). W 9 przypadkach były to próbki ze stali zlewnej i w 12 przypadkach próbki ze stali St3M. Analizowane badania Instytut Spawalnictwa wykonał na próbkach okrągłych o średnicy $10 \mathrm{~mm}(2 \times 1=2$ sztuki) oraz na jednej próbce o średnicy $6 \mathrm{~mm}$. Wszystkie badane próbki w powyższych badaniach pobrano wzdłuż kierunku walcowania poszczególnych blach. Badania rozciągające wykonano na maszynach Zwick/Roell Z600 oraz Instron 4210, a uzyskane wyniki zestawiono w tablicy II. W tablicy tej podano również normowe wymogi materiałowe dla przyjętej stali zlewnej gatunku St52 oraz stali gatunku St3M i 18G2A. Dla badanej stali poszczególnego gatunku (przęsła) obliczono również współczynnik $a=R e / R m$. Wartość tego współczynnika ma duże znaczenie przy określaniu $R e$ stali mostów, w których granice wytrzymałości $R m$ określa się na podstawie badań twardości HB [15]. Wykazane w tablicy II, otrzymane z badań wartości Re i $R m$, każdorazowo mieszczą się w zakresie wartości normowych dla założonego gatunku stali. Łatwo zauważyć bardzo mały rozrzut wartości wytrzymałościowych uzyskanych w danej grupie badanej stali z poszczególnych badań własnych i Instytutu Spawalnictwa.

\begin{tabular}{|c|c|c|c|c|c|c|}
\hline \multirow{2}{*}{ Przęsło } & \multirow{2}{*}{$\begin{array}{l}\text { Stal } \\
\text { rok bud. }\end{array}$} & \multirow{2}{*}{ Badania } & \multicolumn{3}{|c|}{$\begin{array}{c}\text { Właściwości } \\
\text { wytrzymałościowe }\end{array}$} & \\
\hline & & & $\mathrm{Re}_{\mathrm{e}} \mathrm{MPa}$ & $\mathrm{R}_{\mathrm{m}} \mathrm{MPa}$ & $A_{5} \%$ & \\
\hline \multirow{2}{*}{1} & \multirow{2}{*}{$\begin{array}{l}\text { St3M } \\
1970\end{array}$} & $\mathrm{BW}^{1)}$ & 298 & 426 & 33 & 0,27 \\
\hline & & $I^{3)}$ & 316 & 465 & 36 & 0,32 \\
\hline \multirow{2}{*}{2} & \multirow{2}{*}{$\begin{array}{l}\text { St3M } \\
1984\end{array}$} & $\mathrm{BW}^{1)}$ & 297 & 436 & 33 & 0,26 \\
\hline & & $\mathrm{IS}^{3)}$ & 278 & 424 & 35 & 0,25 \\
\hline \multirow{2}{*}{$3 \div 5$} & \multirow{2}{*}{$\begin{array}{c}\text { zlewna } \\
1875\end{array}$} & $\mathrm{BW}^{1)}$ & 376 & 558 & 32 & 0,43 \\
\hline & & $\mathrm{IS}^{3)}$ & 413 & 572 & 34 & 0,43 \\
\hline \multicolumn{3}{|c|}{$\begin{array}{c}\text { Stal zlewna } \\
(\text { St\%2-PN-54/H-84021) }\end{array}$} & $\begin{array}{l}\min . \\
320\end{array}$ & $\begin{array}{c}520 \\
\div 640\end{array}$ & $\min .25$ & $\begin{array}{c}0,62 \\
\div 0,56 \\
\end{array}$ \\
\hline \multicolumn{3}{|c|}{$\begin{array}{c}\mathrm{St3M} \\
(\mathrm{PN}-89 / \mathrm{H}-84023 / 04)\end{array}$} & $\begin{array}{l}\min . \\
240\end{array}$ & $\begin{array}{l}370 \\
\div 470 \\
\end{array}$ & $\min .25$ & $\begin{array}{c}0,65 \\
\div 0,51\end{array}$ \\
\hline \multicolumn{3}{|c|}{$\begin{array}{c}18 \mathrm{G} 2 \mathrm{~A} \\
(\mathrm{PN}-86 / \mathrm{H}-84018)\end{array}$} & $\begin{array}{l}\min . \\
320\end{array}$ & $\begin{array}{l}430 \\
\div 630\end{array}$ & $\min .22$ & $\begin{array}{r}0,65 \\
\div 0,51 \\
\end{array}$ \\
\hline \multicolumn{7}{|c|}{$\begin{array}{l}\text { 1) - wartości średnie z dwóch próbek, 2) - wartości średnie } \\
\text { z trzech próbek, 3) - wartości z badań jednej próbki }\end{array}$} \\
\hline
\end{tabular}

Tablica II. Właściwości wytrzymałościowe stali mostu A w torze nr 1 Table II. Mechanical properties of steel in bridge A under track No. 1

\begin{tabular}{|c|c|c|c|c|c|c|c|c|c|c|c|c|}
\hline \multirow{2}{*}{ Przęsło } & \multirow{2}{*}{$\begin{array}{c}\text { Stal } \\
\text { rok bud. }\end{array}$} & \multirow{2}{*}{ Badania } & \multicolumn{9}{|c|}{ Zawartość pierwiastka, \% } & \multirow{2}{*}{$\mathrm{C}_{\mathrm{e},} \%$} \\
\hline & & & C & $\mathrm{Mn}$ & Si & $P$ & $S$ & $\mathrm{Cr}$ & $\mathrm{Ni}$ & $\mathrm{Cu}$ & Al & \\
\hline \multirow{2}{*}{1} & \multirow{2}{*}{$\begin{array}{l}\text { St3M } \\
1970\end{array}$} & $\mathrm{BW}^{1)}$ & 0,114 & 0,621 & 0,128 & 0,025 & 0,038 & 0,111 & 0,072 & 0,195 & 0,033 & 0,27 \\
\hline & & $\mathrm{IS}^{3)}$ & 0,201 & 0,615 & 0,235 & 0,008 & 0,023 & 0,050 & 0,037 & 0,068 & 0,079 & 0,32 \\
\hline \multirow{2}{*}{2} & \multirow{2}{*}{$\begin{array}{l}\text { St3M } \\
1984\end{array}$} & $\mathrm{BW}^{1)}$ & 0,133 & 0,611 & 0,155 & 0,027 & 0,031 & 0,070 & 0,043 & 0,092 & 18ppm & 0,26 \\
\hline & & $\mathrm{IS}^{3)}$ & 0,141 & 0,538 & 0,123 & 0,019 & 0,033 & 0,063 & 0,035 & 0,062 & 0,004 & 0,25 \\
\hline \multirow{2}{*}{$3 \div 5$} & \multirow{2}{*}{$\begin{array}{c}\text { zlewna } \\
1875\end{array}$} & $\mathrm{BW}^{1)}$ & 0,147 & 1,409 & 0,803 & 0,035 & 0,042 & 0,033 & 0,081 & 0,459 & $51 \mathrm{ppm}$ & 0,43 \\
\hline & & $\mathrm{IS}^{3)}$ & 0,165 & 1,350 & 0,522 & 0,076 & 0,036 & 0,005 & 0,031 & 0,93 & 0,006 & 0,43 \\
\hline \multicolumn{3}{|c|}{ Stal zlewna } & $\begin{array}{c}0,03 \\
\div 0,35\end{array}$ & $\begin{array}{c}0,04 \\
\div 0,75\end{array}$ & $\begin{array}{l}\text { ślady } \\
\div 0,18\end{array}$ & $\begin{array}{l}0,004 \\
\div 0,16\end{array}$ & $\begin{array}{c}0,004 \\
\div 0,115\end{array}$ & $\begin{array}{c}0,11 \\
\div 0,14\end{array}$ & $\begin{array}{c}0,03 \\
\div 0,04\end{array}$ & $\begin{array}{c}0,11 \\
\div 0,14\end{array}$ & $\begin{array}{c}0,01 \\
\div 0,02\end{array}$ & - \\
\hline \multicolumn{3}{|c|}{ St3M } & $\begin{array}{l}\max \\
0,20\end{array}$ & $\begin{array}{l}\min \\
0,40\end{array}$ & $\begin{array}{c}0,12 \\
\div 0,30\end{array}$ & $\begin{array}{c}\max \\
0,050\end{array}$ & $\begin{array}{c}\max \\
0,050\end{array}$ & $\begin{array}{l}\max \\
0,30\end{array}$ & $\begin{array}{l}\max \\
0,30\end{array}$ & - & $\begin{array}{l}\min \\
0,02\end{array}$ & - \\
\hline \multicolumn{3}{|c|}{$18 \mathrm{G} 2 \mathrm{~A}$} & $\begin{array}{l}\max \\
0,20\end{array}$ & $\begin{array}{c}1,00 \\
\div 1,50\end{array}$ & $\begin{array}{c}0,20 \\
\div 0,55\end{array}$ & $\begin{array}{c}\max \\
0,040\end{array}$ & $\begin{array}{c}\max \\
0,040\end{array}$ & $\begin{array}{l}\max \\
0,30\end{array}$ & $\begin{array}{l}\max \\
0,30\end{array}$ & $\begin{array}{l}\max \\
0,30\end{array}$ & $\begin{array}{l}\min \\
0,02\end{array}$ & - \\
\hline
\end{tabular}

Tablica I. Skład chemiczny stali przęset: 1, 2 i 3 $\div 5$ w torze nr 1 mostu A

Table I. Chemical composition of the steel: spans 1, 2 and 3 to 5 in - bridge A, track No. 1

1) - wartości średnie z dwóch próbek, 2) - wartości średnie z trzech próbek, 3) - wartości z badań jednej próbki 
Przykładowo, maksymalne wartości odchyłek dla $R$ e i $R m$ wynoszą:

- dla stali St3M przęsła 1 - od 6,0 do 9,1\%,

- dla stali St3M przęsła 2 - od 2,8 do 6,8\%,

- dla stali zlewnej przęseł 3, 4 i 5 - od 2,5 do 9,8\%.

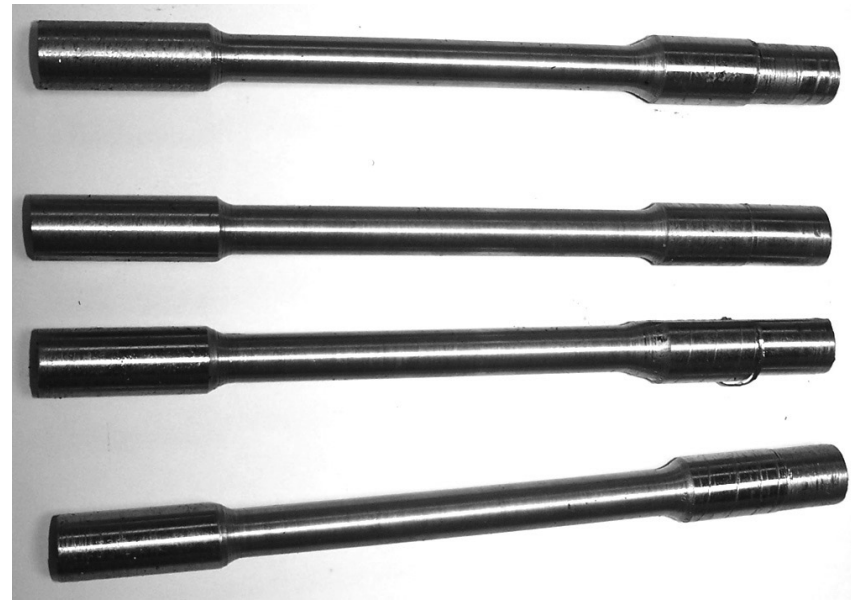

Rys. 4. Próbki z pasów dolnych dźwigarów do badań własnych rozciągania stali

Fig. 4. Specimens from the lower chords of truss girders for tensile tests

Badania udarnościowe pracy łamania KC stali z konstrukcji kratownicowej mostu A w torze nr 1 przeprowadzono oddzielnie dla stali St3M przęseł wolnopodpartych oraz dla stali zlewnej z trójprzęsłowej konstrukcji ciągłej. W badaniach własnych (BW) nie przeprowadzono badań stali gatunku St3M z dźwigarów przęsła 1 (od strony Chyrzyna) wybudowanego w 1970 r. Każdorazowo badania wykonano na próbkach Charpy'ego o wymiarach 10×10×55 mm z karbem V o głębokości $2 \mathrm{~mm}$ i geometrii wg PN-EN ISO 148-1: 2010 (Rys. 5).

Uzyskane średnie wartości KC z badań własnych 2×(5×3) = 30 próbek $\mathrm{w}$ pięciu zakresach temperaturowych oraz badań Instytutu Spawalnictwa $3 \times(3 \times 2)=18$ próbek w trzech zakresach temperaturowych przedstawiono w tablicy III. W tablicy tej podano także temperatury przejścia poszczególnych stali od stanu plastycznego do stanu kruchego (temperatura przejścia plastyczno-kruchego - tp) dla kryterium łamania $27 \mathrm{~J}$ - TKV27. Według wymogów PN-EN 1993-1-10, wartość pracy łamania 27 J przyjmuje się jako wielkość krytyczną wymaganą przez Eurokod 3 dla stali badanych próbek o $\mathrm{A}=80 \mathrm{~mm}^{2}$ uważaną za wartość minimalną w nowych konstrukcjach. Oznacza to, że w nowych konstrukcjach mostowych stal gatunku S355 powinna mieć klasę jakości: K2; N; NL lub M; ML, czyli KC = $27 \mathrm{~J}$ w temperaturze $\leq-30{ }^{\circ} \mathrm{C}[22]$.
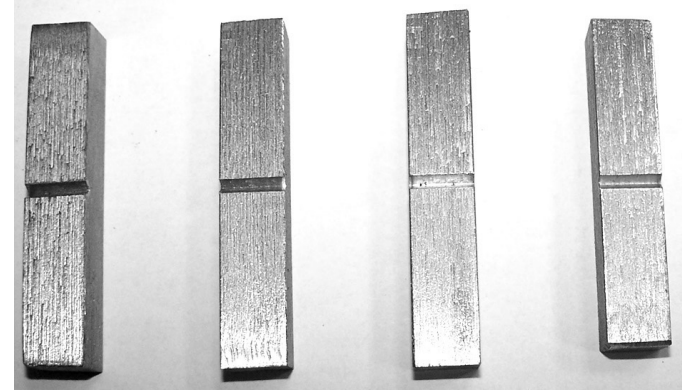

Rys. 5. Próbki z karbem $V$ do badania udarności

Fig. 5. V-notched specimens for toughness tests

Z porównania uzyskanych wartości pracy łamania z badań udarnościowych BW i IS, przedstawionych w tablicy III, wynika znaczny rozrzut ich wartości w niektórych zakresach temperaturowych. Dla stali St3M różnice te wynoszą od 6,7 do $44,4 \%$, a dla stali zlewnej od 8,0 do $37,5 \%$. Według danych literaturowych jest to cecha charakterystyczna dla badań udarnościowych [15]. Generalnie należy stwierdzić, że uzyskane wyniki są porównywalne. O fakcie tym świadczą prawie jednakowe wartości $T_{\mathrm{kV} 27}$ uzyskane z poszczególnych badań.

Badane stale obu gatunków wykazały małą udarność w temperaturze minusowej. Temperatura przejścia tych stali od stanu plastycznego do kruchego wynoszą ok. $-8{ }^{\circ} \mathrm{C}$ dla stali St3M i $+4{ }^{\circ} \mathrm{C}$ dla stali zlewnej. Wyraźny wzrost ich pracy łamania następuje dopiero powyżej temperatury $+10^{\circ} \mathrm{C}$.

\section{Spawać czy nie spawać?}

W wyniku analizy przedstawionych badań, wykazanych w orzeczeniu [20], Instytut Spawalnictwa zaznaczył:

„W podsumowaniu badań można stwierdzić, że badane stale nr 2 i 3 charakteryzują się niezadowalającą spawalnością, ponieważ wykazują wyjątkową skłonność do pękania kruchego w obniżonych temperaturach.” ... „Dlatego badanych stali nie należy łączyć metodami spawalniczymi."

Według autorów referatu wnioski te wydają się dyskusyjne. Faktycznie normy wyrobów hutniczych wymagają, aby praca łamania w określonej temperaturze była nie mniejsza niż $27 \mathrm{~J}$. Jak wykazały badania próbek normalizowanych, warunek ten spełniały również stale przedmiotowego mostu. Pierwotna wartość pracy łamania $\mathrm{w}$ temperaturze $-20{ }^{\circ} \mathrm{C}$ stali zlewnej wynosiła $57 \mathrm{~J}$, a stali St3M aż $130 \mathrm{~J}$. Obecnie niskie wartości 10 i $20 \mathrm{~J}$ są spowodowane procesami starzenia tych stali. Słusznie w normie [23] podano, że dobór stali ze względu na kruche pękanie wg powyższych wymogów: „zaleca się stosować przy doborze stali na nowe konstrukcje. Nie dotyczą one konstrukcji użytkowanych." Poza tym

Tablica III. Wyniki badań udarnościowych stali mostu A w torze nr 1 Table III. Toughness test results for the steel in bridge A under track No. 1

\begin{tabular}{|c|c|c|c|c|c|c|c|c|}
\hline \multirow{2}{*}{ Przęsło } & \multirow{2}{*}{$\begin{array}{c}\text { Stal } \\
\text { rok bud. }\end{array}$} & \multirow{2}{*}{ Badania } & \multicolumn{5}{|c|}{ Praca łamania KV w J } & \multirow{2}{*}{$\begin{array}{c}\mathrm{T}_{\mathrm{KV} 27} \\
{ }^{\circ} \mathrm{C}\end{array}$} \\
\hline & & & $-20^{\circ} \mathrm{C}$ & $-10^{\circ} \mathrm{C}$ & $0{ }^{\circ} \mathrm{C}$ & $10^{\circ} \mathrm{C}$ & $20^{\circ} \mathrm{C}$ & \\
\hline \multirow{2}{*}{1} & \multirow{2}{*}{$\begin{array}{l}\text { St3M } \\
1970\end{array}$} & $\mathrm{BW}^{1)}$ & - & - & - & - & - & - \\
\hline & & $\mathrm{IS}^{3)}$ & 39 & - & 87 & - & 111 & -25 \\
\hline \multirow{2}{*}{2} & \multirow{2}{*}{$\begin{array}{l}\text { St3M } \\
1984\end{array}$} & $\mathrm{BW}^{1)}$ & 21 & 26 & 29 & 52 & 133 & -7 \\
\hline & & $\mathrm{IS}^{3)}$ & 18 & - & 39 & - & 104 & -9 \\
\hline \multirow{2}{*}{$3 \div 5$} & \multirow{2}{*}{$\begin{array}{c}\text { zlewna } \\
1875\end{array}$} & $\mathrm{BW}^{1)}$ & 11 & 19 & 27 & 37 & 46 & 0 \\
\hline & & $\mathrm{IS}^{3)}$ & 8 & - & 25 & - & 35 & +4 \\
\hline $\begin{array}{l}\text { 1) - wartośc } \\
\text { 2) - wartośc }\end{array}$ & nie $z$ trze & $\begin{array}{l}\text { eek } \\
\text { óbek }\end{array}$ & & & & & & \\
\hline
\end{tabular}


norma zaznacza, że reguły te stosuje się do elementów spawanych narażonych na zmęczenie, w których część zakresu zmienności naprężeń jest skutkiem rozciągania, co nie ma miejsca w analizowanych spoinach pachwinowych.

Według autorów referatu w przedmiotowych spoinach nie wystąpią pęknięcia zmęczeniowe. Z konstrukcyjnego punktu widzenia istnieją trzy zasadnicze czynniki, które prowadzą do kruchego pękania przy naprężeniach rozciągających. Są to:

a) obecność ostrego karbu (wtrącenia niemetaliczne),

b) wysoka wartość lokalnych naprężeń rozciągających w obszarze karbu,

c) temperatura eksploatacji konstrukcji niższa od temperatury przejścia w stan kruchy.

Niezaistnienie jednego z tych czynników eliminuje możliwość wystąpienia kruchego pękania. Z orzeczenia [20] wynika, że opiniodawca korzystał z projektu modernizacji mostu i wiadomym było, że problem spawania dotyczy ściskanych spoin pachwinowych o niskim poziomie występujących naprężeń.

Obliczone metodą kierunkową naprężenia w spoinach pachwinowych wynoszą:

$$
\sigma=\frac{0,5 Q_{v i} Y_{f} a+{ }_{2} \Phi_{2}}{2 l_{s} a} ; \quad \sigma_{\perp}=T_{\perp}=\frac{\sigma}{\sqrt{2}}
$$

oraz $\sigma_{\perp} \leq 0,9 \frac{f_{u}}{Y_{M 2}} ; \quad T_{w}=\sigma \sqrt{2} \leq \frac{f_{u}}{\beta_{W} Y_{M 2}}$

gdzie:

- 0,5Qvi = 62,5 kN - nacisk koła poprzez szynę,

- yf = 1,45 - współczynnik obciążenia,

- $a+2=1,21$ - współczynnik klasyfikacyjny,

- $\Phi 2=1,37$ - obliczony współczynnik dynamiczny dla podłużnicy,

- Is = $220 \mathrm{~mm}, \mathrm{a}=8 \mathrm{~mm}-$ dane spoiny,

- $\mathrm{fu}=424 \mathrm{MPa} ; \quad \beta \mathrm{W}=0,9 ; \quad \gamma M 2=1,25$ - wg tablicy II i normy dla słabszej z łączonych części (St3M).

Ostatecznie otrzymano:

$\sigma=43 \mathrm{MPa} ; \sigma_{\perp}=\mathrm{T}_{\perp}=30 \mathrm{MPa} ; \mathrm{T}_{w}=60 \mathrm{MPa}<377 \mathrm{MPa}$

Obliczeniowe naprężenia $\mathrm{w}$ spoinach stanowią jedynie $16 \%$ wartości naprężeń projektowych.

\section{Badania stali podłużnic jezdni mostów}

Celem całkowitego rozwiania wątpliwości dotyczących możliwości spawania podkładek centrujących pod mostownice mostowe (por. rys. 3b) postanowiono wykonać dodatkowe badania stali belek podłużnicowych jezdni mostów. W tym celu wycięto cztery próbki pasów górnych podłużnic, a ich stal poddano:

- analizie składu chemicznego,

- badaniu twardości metodą Brinella celem wyznaczenia $\mathrm{R}_{\mathrm{m}}$ i $\mathrm{R}_{\mathrm{e}}$,

- badaniom rozciągania złączy doczołowych,

- badaniom udarnościowym na próbkach Charpy'ego,
- oszacowaniu spawalności na podstawie składu chemicznego.

Skład chemiczny określono z badań stali czterech próbek, a ich wyniki zamieszczono w tablicy IV. Łatwo zauważyć, że uzyskane wartości zawartości poszczególnych pierwiastków są porównywalne z wartościami zamieszczonymi w tablicy I, które uzyskano z badań stali kratownicowych dźwigarów nośnych.

Pomiar twardości metodą Brinella przeprowadzono twardościomierzem typ B3Cs, a średnie wyniki z trzech pomiarów przedstawiono $\mathrm{w}$ tablicy $\mathrm{V}$, (kol. 5. Twardość mierzono w tzw. warunkach standardowych, używając kulki stalowej o średnicy $D=10 \mathrm{~mm}$, przy obciążeniu utrzymywanym przez $t=15 \mathrm{~s}$. RmB wyznaczono wg PN-EN ISO 6506-4:2002, a $\mathrm{R}_{\mathrm{eB}}$ określono przy przyjętej wartości ilorazu $a=R_{e B} / R_{m B}=0,7$ wg tablicy II.

Tablica V. Właściwości mechaniczne według twardości Table V. Mechanical properties according to toughness

\begin{tabular}{|c|c|c|c|c|c|c|c|}
\hline \multirow{2}{*}{$\begin{array}{l}\text { Przęsło } \\
\text { i most }\end{array}$} & \multirow{2}{*}{ Stal } & \multicolumn{2}{|c|}{ Próbka } & \multirow{2}{*}{$\begin{array}{c}\emptyset \text { odcisku } \\
\mathrm{mm}\end{array}$} & \multirow{2}{*}{$\begin{array}{l}\mathrm{HB} \\
10\end{array}$} & \multirow{2}{*}{$\mathrm{R}_{\mathrm{mB}}$} & \multirow{2}{*}{$\mathrm{R}_{\mathrm{eB}}$} \\
\hline & & $\begin{array}{c}\mathrm{t} \\
\mathrm{mm}\end{array}$ & Profil & & & & \\
\hline $1-A$ & \multirow{2}{*}{ St3M } & 16,8 & HEB240 & 5,25 & 128 & 426 & 298 \\
\hline $2-A$ & & 15,2 & HEB220 & 5,25 & 128 & 426 & 298 \\
\hline \multicolumn{4}{|c|}{ Wartość średnia } & 5,25 & 128 & 426 & 298 \\
\hline $4-A$ & \multirow{2}{*}{ zlewna } & 19,6 & IP280 & 2,65 & 167 & 559 & 391 \\
\hline $2-B$ & & 18,2 & IP260 & 4,70 & 163 & 547 & 387 \\
\hline \multicolumn{4}{|c|}{ Wartość średnia } & 4,675 & 165 & 553 & 387 \\
\hline
\end{tabular}

Uzyskane wartości $R_{e B}$ i $R_{m B}$ są prawie analogiczne jak wartości w tablicy II. Określone wartości dla stali gatunku St3M są identyczne jak w badaniach BW, a w porównaniu ze stalą zlewną różnice dla wartości $R_{e}$ i $R_{m}$ wynoszą odpowiednio $+2,9$ i $-0,9 \%$.

Badania rozciągające złączy spawanych ze stali zlewnej podłużnic (próbki nr 1 z i 2z) oraz ze stali St3M (próbki nr 3 i 4) przeprowadzono zgodnie z wymaganiami PN-EN ISO 4136: 2013. Przekrój poprzeczny ich strefy pomiarowej wynosił $25 \times 15$ i $25 \times 12 \mathrm{~mm}$. Po odpowiednim przygotowaniu krawędzi do spawania, ręcznie wykonano dwustronne spoiny. Spawano w pozycji podolnej (A) z użyciem elektrod zasadowych z niską zawartością wodoru: BASIC 7018 o średnicy 4,0 mm firmy Lincoln Electric, które suszone były w temperaturze $350{ }^{\circ} \mathrm{C}$ przez okres $4 \mathrm{~h}$. Według ISO 2560-A są to elektrody E42 4B $42 \mathrm{H} 5$.

Badania rozciągające przeprowadzono na maszynie ZD 100, a ich wyniki przedstawiono na rysunku 6.

Tylko jedna próbka (nr 2z) została zerwana w materiale na odcinku pomiarowym poza spoiną, w odległości $32 \mathrm{~mm}$ od jej osi (rys. 7). Pozostałe trzy próbki zostały zerwane

Tablica IV. Skład chemiczny stali belek podłużnicowych

Table IV. Chemical composition of the steel from stringers

\begin{tabular}{|c|c|c|c|c|c|c|c|c|c|c|c|}
\hline \multirow{2}{*}{$\begin{array}{c}\text { Przęsto } \\
\text { i most }\end{array}$} & \multirow{2}{*}{$\begin{array}{c}\text { Stal } \\
\text { rok bud. }\end{array}$} & \multicolumn{9}{|c|}{ Zawartość pierwiastka, \% } & \multirow{2}{*}{$\begin{array}{l}\mathrm{Ce} \\
\%\end{array}$} \\
\hline & & $\mathrm{C}$ & $\mathrm{Mn}$ & Si & $\mathrm{P}$ & $S$ & $\mathrm{Cr}$ & $\mathrm{Ni}$ & $\mathrm{Cu}$ & Al & \\
\hline \multirow{2}{*}{$1-\mathrm{A}$} & \multirow{2}{*}{$\begin{array}{l}\text { St3M } \\
1970 \\
1980 \\
\end{array}$} & 0,131 & 0,684 & 0,195 & 0,016 & 0,030 & 0,086 & 0,043 & 0,093 & 0,067 & 0,27 \\
\hline & & 0,127 & 0,954 & 0,195 & 0,012 & 0,011 & 0,016 & 99ppm & 0,023 & 0,063 & 0,29 \\
\hline \multicolumn{2}{|c|}{ Wartość średnia } & 0,129 & 0,819 & 0,195 & 0,014 & 0,021 & 0,051 & 0,022 & 0,058 & 0,065 & 0,28 \\
\hline $4-\mathrm{A}$ & \multirow{2}{*}{$\begin{array}{c}\text { zlewna } \\
1875\end{array}$} & 0,142 & 1,738 & 0,523 & 0,028 & 0,027 & $72 \mathrm{ppm}$ & 0,040 & 0,364 & $44 \mathrm{ppm}$ & 0,46 \\
\hline $2-B$ & & 0,124 & 1,714 & 0,494 & 0,027 & 0,027 & 0,012 & 0,040 & 0,417 & 0,011 & 0,44 \\
\hline \multicolumn{2}{|c|}{ Wartość średnia } & 0,133 & 1,726 & 0,508 & 0,028 & 0,027 & 0,006 & 0,040 & 0,390 & 0,006 & 0,45 \\
\hline
\end{tabular}


w stopiwie, w osi spoiny. Na ich przełomach stwierdzono ciągły brak przetopu o szerokości od 2,1 do 2,8 mm (rys. 7). Oznacza to, że zerwanie nastąpiło w stopiwie przy naprężeniach o wartości około $600 \mathrm{MPa}$, które po przeliczeniu na przekrój stalowy dają wartości Rm od 362 do 536 $\mathrm{MPa}$, zapisane na rysunku 6.

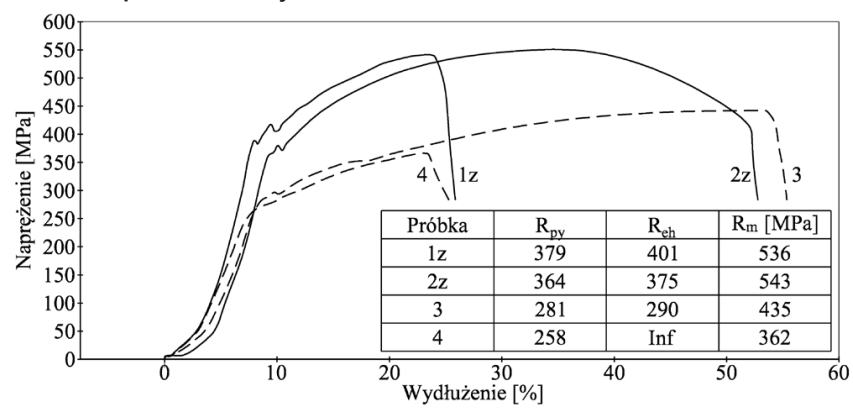

Rys. 6. Wykresy rozciągania stali z czterech podłużnic

Fig. 6. Stress-strain curves of the steel from four stringers
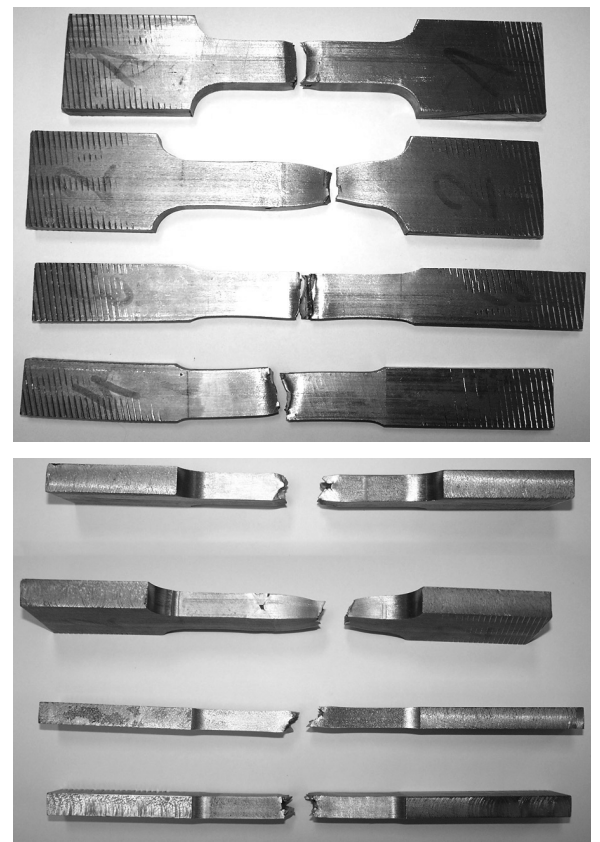

Rys. 7. Widok próbek ze złączami doczołowymi po badaniu na rozciąganie

Fig. 7. View of specimens with butt welds after tensile tests

Jednocześnie średnie wartości granicy plastyczności $R_{\text {eh }}$ wynoszą $388 \mathrm{MPa}$ dla stali zlewnej i $290 \mathrm{MPa}$ dla stali St3M. Są to wartości analogiczne do uzyskanych $\mathrm{z}$ badań twardości i zamieszczonych $\mathrm{w}$ tabl. V. Różnice dla $R_{m}$ wynoszą od $-2,4$ do $-6,3 \%$, a dla $R_{\text {eh }}$ od 0,3 do $-2,7 \%$.

Badania udarnościowe pracy łamania KC stali z dwuteowych belek podłużnicowych jezdni mostów przeprowadzono na próbkach Charpy'ego zgodnie z metodyką omówioną przy badaniach stali z kratownicowych dźwigarów nośnych (por. tabl. III).

W przedstawionych w tablicy VI wynikach badań łatwo zauważyć duży rozrzut uzyskanych wartości z badań poszczególnego gatunku stali w danej temperaturze. Tym niemniej uzyskane wartości temperatury dotyczącej ich przejścia od stanu plastycznego do kruchego są porównywalne z wartościami określonymi w tablicy III. Na uwagę zasługuje fakt, zniszczenia aż 21 próbek $(87,5 \%)$ ze złomem z rozwarstwieniem. Tylko 3 próbki stali zlewnej (dwie w $-20^{\circ} \mathrm{C}$ i jedna $\mathrm{w}-10^{\circ} \mathrm{C}$ ) uległy zniszczeniu ze złomem całkowitym.

Spawalność metalurgiczną stali podłużnic określono na podstawie niżej podanych wskaźników $[2,9,15]$; przy czym obliczone według danych z tablicy IV wartości bez nawiasów dotyczą stali St3M, a w nawiasach stali zlewnej:

a) równoważnik chemiczny węgla (rys. 5)
$\mathrm{C}_{\mathrm{e}}=\mathrm{C}+\frac{\mathrm{Mn}}{6}+\frac{\mathrm{Cr}+\mathrm{Mo}+\mathrm{V}}{5}+\frac{\mathrm{Ni}+\mathrm{Cu}}{15}=0,28$;

$$
(0,45)<0,42 \% \text { i }(>0,40 \%)
$$

b) wskaźnik odporności materiału na pękanie gorące

$$
\begin{aligned}
H C S= & 1000\left(S+P+\frac{S i}{25}+\frac{N i}{100}\right) \\
& \frac{C}{3 M n+C r+M o+V}=2,2 ;(1,94)<4 \%
\end{aligned}
$$

c) wskaźnik oceny skłonności do pękania zimnego $(\mathrm{t}=17 \mathrm{i} 20 \mathrm{~mm})$

$$
\begin{aligned}
& C_{e}^{\prime}=C+\frac{M n}{6}+\frac{P}{2}+\frac{M o}{4}+\frac{N i}{15}+\frac{C u}{13}+\frac{C r+V}{5}+ \\
& +0,0024 t=0,33 ;(0,52)<0,4 \% i(>0,4 \%)
\end{aligned}
$$

d) twardość strefy wpływu ciepła

$\mathrm{HV}_{\max }=12000 \mathrm{C}_{\mathrm{e}}^{\prime}-200=197 ;(421)<350 \mathrm{HV}$ i $(>350 \mathrm{HV})$

Stal gatunku St3M jest spawalna bez ograniczeń, natomiast stal zlewna z $1875 \mathrm{r}$. jest spawalna warunkowo mimo (rys. 8), że prawie wszystkie obliczone wskaźniki $(4,6$ i 7) przekraczają wartości graniczne. Przy spawaniu podkładek centrujących do podłużnic z tej stali należy zastosować technologię podaną w podsumowaniu.

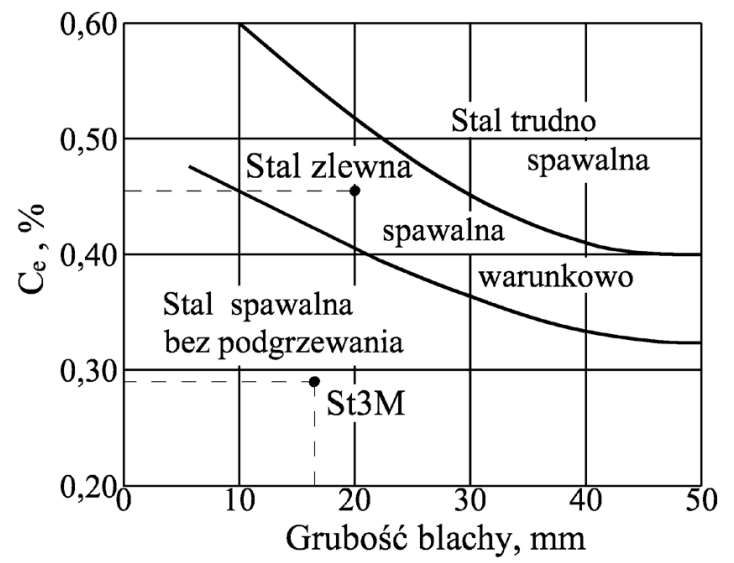

Rys. 6. Spawalność stali zlewnej i stali St3M podłużnic

\begin{tabular}{|c|c|c|c|c|c|c|c|c|}
\hline \multirow{2}{*}{$\begin{array}{c}\text { Przęsło } \\
\text { i most }\end{array}$} & \multirow{2}{*}{ Stal } & \multirow{2}{*}{ Profil } & \multicolumn{5}{|c|}{ Praca łamania KV w J } & \multirow{2}{*}{$\begin{array}{c}\mathrm{T}_{\mathrm{KV} 27} \\
{ }^{\circ} \mathrm{C}\end{array}$} \\
\hline & & & $-20^{\circ} \mathrm{C}$ & $-10^{\circ} \mathrm{C}$ & $0^{\circ} \mathrm{C}$ & $10^{\circ} \mathrm{C}$ & $20^{\circ} \mathrm{C}$ & \\
\hline \multirow{3}{*}{$\begin{array}{l}1-A \\
2-A\end{array}$} & \multirow{3}{*}{ St3M } & \multirow{3}{*}{$\begin{array}{l}\text { HTB240 } \\
\text { HEB220 }\end{array}$} & 7,1 & - & 77,2 & - & 73,6 & -14 \\
\hline & & & 14,1 & - & 81,3 & - & 83,0 & -16 \\
\hline & & & 19,5 & - & 91,9 & - & 90,8 & -18 \\
\hline \multicolumn{3}{|c|}{ Wartość średnia } & 13,6 & - & 83,5 & - & 82,5 & -16 \\
\hline \multirow{3}{*}{$\begin{array}{l}4-A \\
2-B\end{array}$} & \multirow{3}{*}{ zlewna } & \multirow{3}{*}{$\begin{array}{l}\text { IP280 } \\
\text { IP260 }\end{array}$} & $5,8=$ & 18,1 & 22,7 & 24,8 & 37,3 & +12 \\
\hline & & & 10,1 & $18,9=$ & 25,5 & 25,0 & 45,2 & +11 \\
\hline & & & $15,0=$ & 23,1 & 27,7 & 29,8 & 56,1 & -1 \\
\hline \multicolumn{3}{|c|}{ Wartość średnia } & 10,3 & 20,0 & 25,3 & 26,5 & 46,2 & +7 \\
\hline
\end{tabular}

Fig. 6. Weldability of cast steel and St3M steel from stringers

Tablica VI. Wyniki badań udarnościowych stali podłużnic pomostów belkowych mostów

Table VI. Toughness test results of steel from deck stingers 


\section{Podsumowanie}

W trakcie badań stali mostu kolejowego A w torze nr 1, dwa niezależne zespoły (BW - badania własne autorów referatu i IS - Instytutu Spawalnictwa) uzyskały prawie identyczne wyniki dotyczące zagadnień materiałowych i wytrzymałościowych (por. tabl. I-III). W podsumowaniu tych wyników IS, w przeciwieństwie do BW, stwierdził niezadowalającą spawalność stali i zakwestionował możliwość jej łączenia metodami spawalniczymi.

Według autorów referatu zostało to spowodowane niepełną znajomością zakresu przewidywanych prac spawalniczych w trakcie modernizacji mostów oraz błędną interpretacją zaleceń normowych. Fakt ten potwierdziły wyniki dodatkowych, rozszerzonych badań stali dwuteowych belek podłużnicowych, do których bezpośrednio są łączone podkładki centrujące za pomocą spoin pachwinowych a $=8 \mathrm{~mm}$. W konstrukcjach trójprzęsłowych ze stali zlewnej, w torze nr 1 , w miejscu podkładki odcinek pasa górnego podłużnicy długości $400 \mathrm{~mm}$ należy podgrzać do temperatury $200{ }^{\circ} \mathrm{C}$. Podgrzewać palnikiem z użyciem propan-butanu w celu wyeliminowania ewentualnego nawęglenia stali, a do spawania używać elektrod zasadowych niskowodorowych, np. oznaczonych wg ISO 2560-A jako E42 4B 42 H5.

Zaskakującym jest fakt uzyskania jednakowych wartości Re i Rm z badań statycznego rozciągania próbek okrągłych i płaskich ze stali gatunku St3M oraz ze stali zlewnej z wartościami określonymi na podstawie pomiarów twardości Brinella, które traktuje się jako przybliżone.

\section{Literatura}

[1] Hołowaty J., Wichtowski B.: O stanie technicznym najstarszego w Polsce wiaduktu drogowego ze stali zlewnej. Inżynieria i Budownictwo, nr 7-8/2013.

[2] Wichtowski B., Woźniak Z.: Właściwości stali zlewnej kratownicowego mostu kolejowego po 122 latach eksploatacji. Inżynieria i Budownictwo, nr 4/2006.

[3] Hołowaty J., Wichtowski B.: Properties of Structural Steel used in Early Railway Bridges. Structural Engineering International 4/2013.

[4] Bakar A. A., Dow R. S.: Collision and Grouping of Ships. Newcastle University, 2010.

[5] Spal L.: Przebudowa konstrukcji stalowych. Arkady, Warszawa 1973.

[6] Wichtowski B., Hołowaty J.: Ocena właściwości stali konstrukcyjnych modernizowanego mostu na linii kolejowej nr 353. Inżynieria i Budownictwo,nr 8/2014.

[7] Rabiega J., Dudziński W.: Badania połączeń spawanych konstrukcji nośnej w procesie naprawy starego mostu kolejowego. Inżynieria i Budownictwo, nr 11/2014.

[8] Fabiszewski A.: Warunki naprężeniowe powstania kruchych pęknięć w konstrukcjach stalowych pod wpływem wad spawalniczych. Zeszyty Naukowe Politechniki Szczecińskiej $\mathrm{Nr}$ 29. Szczecin 1962.

[9] Rykaluk K.: Pęknięcia w konstrukcjach stalowych. Dolnośląskie Wydawnictwo Edukacyjne, Wrocław 1999.

[10] Wichtowski B.: Wytrzymałość zmęczeniowa spawanych złączy doczołowych w stalowych mostach kolejowych. Prace Naukowe Politechniki Szczecińskiej nr 572, KTK1. Wydawnictwo Uczelniane PS. Szczecin 2002.

[11] Brózda J., Pilarczyk J.: Problemy spawania stali ze starych konstrukcji przemysłowych. Przegląd Spawalnictwa, nr 9/1972.

[12] Mryka J.: Problemy spawalnicze naprawy starych stalowych konstrukcji przemysłowych. Przegląd Spawalnictwa, nr 2/1973.
[13] Ferenc K.: Technologie spawania konstrukcji budowlanych $w$ remontach i naprawach $w$ tym łączenia starych konstrukcji z nowymi. XXIII Ogólnopolska Konferencja Warsztat Pracy Projektanta Konstrukcji, Szczyrk 2008.

[14] Wichtowski B., Hołowaty J.: Analiza właściwości materiałowych i spawalności stali zlewnej mostów kolejowych. Inżynieria i Budownictwo, nr 5/2013.

[15] Wichtowski B., Hołowaty J.: Badania udarnościowe stali zlewnej mostów kolejowych. Inżynieria i Budownictwo, $\mathrm{nr} 1 / 2014$.

[16] Albrecht R.: Richtlinien zum Brückenbau. Band 1 - Stählerne Brücken einschließlich Stahlträger in Beton und Verbundkonstruktionen. Bauverlag Gmbh, Wiesbaden und Berlin 1975.

[17] Hołowaty J., Wichtowski B.: Badania stali dwóch mostów kratownicowych na linii kolejowej nr 273. (referat zgłoszony na XXVII Konferencję Naukowo-Techniczną „Awarie Budowlane", Międzyzdroje 2015).

[18] Wichtowski B., Pakos R.: Zagadnienia materiałowo-spawalnicze modernizowanego stalowego mostu kolejowego na linii 408. Przegląd Spawalnictwa, nr 2/2014.

[19] Blicharski M.: Inżynieria materiałowa - stal. WNT, Warszawa 2011.

[20] Orzeczenie Nr ZB/62/2014 pt.: „Określenie spawalności elementów wyciętych zkonstrukcji mostów kolejowych na linii nr 273 Chyrzyno-Kostrzyn, tor nr 1." IS w Gliwicach, 03.10.2014.

[21] Stahl im Hochbau. Zwölfte, Verlag Stahleisen M.B.H. Düsseldorf 1935.

[22] Wichtowski B.: Wymagania materiałowo-spawalnicze w mostach stalowych według zaleceń PN-EN 1993-2. Inżynieria i Budownictwo, nr 11/2013.

[23] PN-EN 1993-1-10:2007 Eurokod 3: Projektowanie konstrukcji stalowych - Część 1-10: Dobór stali ze względu na odporność na kruche pękanie i ciągliwość międzywarstwową. 